\begin{tabular}{llcccc|rr} 
Volume & $12, \quad$ Nomor & $1, \quad$ Mei & 2020, & pp $1-12$ & Copyright & C & 2017 \\
Jurnal & Akuntansi, & Program & Studi & Akuntansi, & Fakultas & Ekonomi, \\
Universitas & Kristen & Maranatha. & ISSN & $2085-8698$ & e-ISSN & $2598-4977$.
\end{tabular}

http://journal.maranatha.edu

\title{
Pengaruh Agency Cost terhadap Nilai Perusahaan dengan Transparansi Informasi sebagai Variabel Moderasi
}

\author{
Dewi Kusuma Wardani \\ Fakultas Ekonomi Program Studi Akuntansi Universitas Sarjanawiyata Tamansiswa \\ (Jl. Kusumanegara No. 121 Yogyakarta) \\ dewifeust@gmail.com \\ Wahyu Tri Susilowati \\ Fakultas Ekonomi Program Studi Akuntansi Universitas Sarjanawiyata Tamansiswa \\ (Jl. Kusumanegara No. 121 Yogyakarta) \\ triw8331@gmail.com
}

\begin{abstract}
This study aims to examine the effect of agency costs on firm value with information transparency as a moderating variable. The sample used in this study is manufacturing. The research sample was taken with the object of manufacturing companies during 2013-2017, based on the purposive sampling method obtained by 58 manufacturing companies. Testing of this study uses simple regression analysis and the value of the absolute difference test. The results showed that agency costs have a positive effect on firm value. Information transparency cannot moderate the effect of agency cost on firm value. So the implication of this research is that a company that has a high agency cost will have a high company value, because it can be used as a shareholder to oversee manager's actions to support the company's value so that it becomes even better. The transparency of information provided by the company to investors or shareholders can not affect their interest in investing, because investors and shareholders are usually more likely to see the profits or profits generated by the company.
\end{abstract}

Keywords: Agency Cost, Information Transparency, Firm Value

\begin{abstract}
Abstrak
Penelitian ini bertujuan untuk menguji pengaruh biaya agensi terhadap nilai perusahaan dengan transparansi informasi sebagai variabel moderasi. Sampel yang digunakan dalam penelitian ini adalah manufaktur. Sampel penelitian diambil dengan objek perusahaan manufaktur selama tahun 2013-2017, berdasarkan metode purposive sampling yang
\end{abstract}


diperoleh 58 perusahaan manufaktur. Pengujian penelitian ini menggunakan analisis regresi sederhana dan nilai uji nilai selisih mutlak. Hasil penelitian menunjukkan bahwa biaya agensi memiliki efek positif pada nilai perusahaan. Transparansi informasi tidak dapat memoderasi pengaruh agency cost terhadap nilai perusahaan.Maka implikasi dari penelitian ini adalah perusahaan yang mempunyai agency cost yang tinggi maka akan memiliki nilai perusahaan yang tinggi, karena hal tersebut dapat dijadikan pemegang saham untuk mengawasi tindakan manajer guna menunjang nilai perusahaan agar semakin lebik baik lagi. Adanya transparansi informasi yang diberikan perusahaan kepada investor atau pemegang saham tidak dapat berpengaruh terhadap minat mereka untuk berinvestasi, karena investor dan pemegang saham biasanya lebih cenderung melihat laba atau profit yang dihasilkan oleh perusahaan.

Kata Kunci: Agency Cost, Transparansi Informasi, Nilai Perusahaan

\section{Pendahuluan}

Pada zaman modern saat ini, persaingan antar perusahaan semakin ketat, karena perusahaan dituntut untuk mengikuti perkembangan dunia teknologi informasi yang semakin pesat agar dapat bertahan dan menghasilkan laba yang maksimal. Disamping mengikuti perkembangan di zaman modern ini, perusahaan juga harus dapat mengontrol potensi baik financial maupun non financial dalam meningkatkan nilai perusahaan untuk jangka panjang. Sebuah perusahaan didirikan tentunya mempunyai tujuan yang jelas, baik dalam jangka pendek maupun jangka panjang. Salah satu tujuan utama dari perusahaan adalah dapat memberikan laba yang maksimal serta kemakmuran bagi pemegang saham maupun pemilik perusahaan. Menurut (Erawati \& Latifah (2018) nilai perusahaan merupakan harga yang terjadi ketika terdapat interaksi oleh para penjual dan pembeli saham yang dilatarbelakangi oleh harapan terhadap laba perusahaan, sehingga dapat mencerminkan kinerja perusahaan bagi persepsi pemegang saham. Pemegang saham menilai perusahaan itu baik, jika perusahaan dapat memberikan sinyal positif kepada investor dalam peningkatan nilai perusahaan dan dapat memperbaiki kinerja perusahaan.
Nilai perusahaan yang tinggi akan mempengaruhi kemakmuran pemegang saham.

Untuk mencapai kemakmuran dan kesejahteraan pemegang saham harus diiringi dengan adanya peningkatan harga saham. Semakin tinggi nilai perusahaan yang tertera pada harga saham, maka perusahaan dianggap mampu memberikan kemakmuran bagi pemegang saham. Jika pemegang saham mendapatkan kemakmuran, maka dapat berdampak positif bagi perusahaan, yakni pemegang saham akan tetap bertahan dalam investasinya serta dapat menarik calon investor untuk dapat menginvestasikan modalnya ke perusahaan tersebut. Upaya yang dilakukan pihak manajemen guna menambah tingkat nilai perusahaan yaitu dengan memaksimalkan nilai sekarang dari semua keuntungan pemegang saham yang diharapkan dapat diperoleh di masa depan. Nilai perusahaan sangatlah penting bagi investor karena akan dijadikan sebagai indikator bagi pasar dalam memberi penilaian perusahaan secara keseluruhan (Harventy, 2016).

Kasus yang terkait dengan nilai perusahaan yaitu kasus pada PT Sepatu Bata Tbk yang melaporkan bahwa kinerja perusahaan pada tahun 2016 mengalami penurunan laba bersih yaitu dari $67,70 \%$ turun menjadi $\mathrm{Rp}$ 
42,23 miliar atau Rp 32,49 per saham dibandingkan $\mathrm{Rp} \quad 129,52$ miliar atau Rp 99,63 per saham pada tahun 2015. Penurunan kinerja PT Sepatu Bata pada tahun 2016 disebabkan oleh adanya penurunan pendapatan pokok. Penurunan pendapatan pokok PT Sepatu Bata Tbk yang sebelumnya sebesar $2,82 \%$ turun menjadi Rp 999,80 pada tahun 2016. Selain itu PT Sepatu Bata juga mengalami penurunan laba yang tidak sedikit yaitu sebesar Rp 154,89 miliar menjadi Rp 66,05 miliar. Hal tersebut dikarenakan adanya kerugian dari pelepasan aset tetap senilai $\mathrm{Rp} 121,03$ miliar. Dengan adanya penurunan laba bersih yang dialami oleh beberapa perusahaan mengakibatkan turunnya nilai perusahaan (www.britama.com, 2016).

Salah satu hal yang mempengaruhi turunnya nilai perusahaan adalah agency cost. Agency cost adalah biaya yang dikeluarkan guna memastikan manajer untuk bertindak sesuai kepentingan prinsipal. Agency cost ini disebabkan oleh pengaruh konflik kepentingan antara manajer dan pemegang saham, yang dapat menimbulkan biaya yang berlebih yaitu free cash flow. Manajer lebih senang memanfaatkan free cash flow dengan cara menginvestasikan dana tersebut pada proyek-proyek yang dapat menghasilkan keuntungan, karena hal ini dapat dapat meningkatkan insentif yang diterimanya. Di sisi lain, pemegang saham berharap dari sisa dana tersebut dapat dibagikan sehingga akan meningkatkan kemakmuran dan kesejahteraan pemegang saham (Khan et al, 2012).

Hubungan antara agency cost terhadap nilai perusahaan masih menjadi perdebatan, pasalnya ada penelitian yang menyebutkan bahwa agency cost memiliki hubungan positif dan ada juga yang menyebutkan agency cost memiliki hubungan negatif terhadap nilai perusahaan. Adityamurti \& Ghozali (2017) menemukan bahwa agency cost berpengaruh positif terhadap nilai perusahaan, disisi lain Wellalage \& Locke
(2013) dan Mustapha (2011) menemukan bahwa agency cost berpengaruh negatif terhadap nilai perusahaan. Oleh karena itu perlu dikaji faktor yang bisa mengurangi dampak negatif agency cost terhadap nilai perusahaan (Wardani \& Juliani, 2018).

Proksi dari transparansi informasi adalah Corporate Social Responsibility (CSR). CSR adalah tanggung jawab perusahaan terhadap seluruh pemangku kepentingan seperti karyawan, pemegang saham, konsumen, masyarakat dan lingkungan sekitar. Transparansi informasi dapat memperlemah pengaruh negatif agency cost terhadap nilai perusahaan. Ketika transparansi informasi tinggi maka manajer tidak dapat memanfaatkan agency cost untuk kepentingan pribadinya sehingga konflik kepentingan antara manajer dan pemegang saham akan semakin rendah. Ketika transparansi informasi rendah maka adanya agency cost dapat dimanfaatkan manajer untuk kepentingan pribadinya. Hal ini dikarenakan dengan adanya transparansi informasi maka investor akan mendapatkan informasi yang lebih banyak daripada ketika transparansi informasi rendah sehingga agency cost yang dilakukan manajer sifatnya adalah bermanfaat bagi investor dan tidak hanya bagi oportunistik manajer. Hal ini menyebabkan transparansi informasi dapat memperlemah pengaruh negatif agency cost terhadap nilai perusahaan.

Sesuai dengan uraian yang telah dijelaskan diatas serta adanya perbedaan hasil penelitian peneliti sebelumnya, pada penelitian ini penulis akan melakukan penelitian mengenai pengaruh agency cost terhadap nilai perusahaan dengan transparansi informasi sebagai variabel moderasi.

\section{Rumusan Masalah}

Adapun rumusan masalah berdasarkan latar belakang adalah sebagai berikut:

a. Apakah agency cost berpengaruh negatif terhadap nilai perusahaan? 
b. Apakah transparansi informasi dapat memperlemah pengaruh negatif agency cost terhadap nilai perusahaan?

\section{Tujuan Penelitian}

Ada beberapa tujuan penelitian sebagai berikut:

a. Untuk menguji pengaruh negatif agency cost terhadap nilai perusahaan.

b. Untuk menguji transparansi informasi dapat memperlemah pengaruh negatif agency cost terhadap nilai perusahaan.

\section{Kerangka Teoritis dan Hipotesis}

\section{Free Cash Flow Theory}

Teori arus kas bebas menjelaskan bahwa perusahaan dengan substansial free cash flow cenderung menghadapi konflik kepentingan antara manajer dan pemegang saham. Manajer selaku agen yang mempunyai kewajiban kontrak oleh perusahaan dengan dana yang dihasilkan dari operasi tersebut untuk keuntungan mereka sendiri dan bukan untuk kepentingan pemegang saham. Pemegang saham juga menginginkan para manajer untuk menginvestasikan uangnya dalam proyek-proyek yang dapat memaksimalkan nilai saham mereka dengan memberikan tunjangan (Khan et al, 2012).

Ferreira \& Vilela (2004) mengemukakan bahwa manajer lebih senang menahan kas bebas untuk investasi perusahaan dengan menahan uang tunai untuk meningkatkan jumlah aset dibawah kendali mereka. Jika manajer memiliki uang tunai untuk diinvestasikan, maka manajer tidak perlu mengumpulkan dana eksternal dan memberikan informasi yang rinci mengenai pasar modal kepada pasar modal proyek investasi perusahaan, sehingga manajer dapat melakukan investasi akan tetapi hal tersebut memberikan dampak negatif kepada kekayaan yang dimiliki oleh pemegang saham.
Menurut teori free cash flow perusahaan lebih senang dengan pendanaan internal daripada pendanaan eksternal, sehingga dengan adanya perusahaan lebih senang pendanaan internal, maka perusahaan itu akan menggunakan aliran dana kas bebas untuk keperluan investasi. Berbeda halnya dengan pemegang saham mereka menginginkan kas tersebut dibagikan sebagai deviden, oleh karena itu agency cost akan berpengaruh negatif terhadap nilai perusahaan.

\section{Signaling Theory}

Teori sinyal menjelaskan mengenai tata cara peusahaan dalam memberikan informasi pada pengguna laporan keuangan. Apabila laba yang diperoleh perusahaan menurun, hal tersebut akan menjadi sinyal bahwa kinerja perusahaan memburuk, sebaliknya apabila laba perusahaan meningkat maka akan menjadi sinyal bahwa kinerja perusahaan meningkat. Informasi yang diungkapkan oleh perusahaan sangatlah penting, karena informasi tersebut nantinya akan dijadikan sebagai bahan pertimbangan keputusan untuk investasi pihak diluar perusahaan (Theresia \& Nuritomo, 2016).

Transparansi informasi dapat membantu mengurangi agency cost yang mungkin terjadi pada perusahaan. Semakin tinggi transparansi informasi pada suatu perusahaan, maka semakin baik pula keadaan perusahaan dimata pemegang saham, karena apabila perusahaan mempunyai transparansi informasi yang tinggi maka perusahaan akan terhindar dari arus kas berlebih dan dapat menimbulkan pembiayaan utang pada perusahaan yang mempunyai pertumbuhan perusahaan yang rendah.

\section{Nilai Perusahaan}

Nilai perusahaan adalah pandangan investor pada tingkat keberhasilan perusahaan yang sering dihubungkan dengan harga saham dan nilai tambah bagi pemegang saham. Semakin tinggi harga saham, maka nilai 
perusahaan juga akan semakin tinggi pula. Nilai perusahaan dapat dicerminkan melalui harga saham biasa perusahaan, yang berfungsi untuk investasi perusahaan, pendanaan dan keputusan deviden (Partha \& Noviari, 2016). Menurut Partha \& Noviari (2016) indikator pada nilai perusahaan dapat dilihat dari harga saham yang diperjualbelikan dalam Bursa Efek Indonesia (BEI) bagi perusahaan go public.

Sugiyanto (2016) menjelaskan bahwa didirikannya sebuah perusahaan tentunya memiliki tujuan yang jelas yaitu meningkatkan nilai perusahaan. Dalam meningkatkan nilai perusahaan, perusahaan harus mampu mencapai keuntungan yang maksimal. Di samping itu, perusahaan juga harus mampu menyejahterakan pemegang saham. Apabila nilai perusahaan meningkat maka perusahaan mampu memaksimumkan kemakmuran pemegang saham. Semakin tinggi harga saham, maka semakin tinggi nilai perusahaan. Nilai perusahaan yang tinggi menggambarkan harga saham yang tinggi pada suatu perusahaan.

\section{Agency Cost}

Djumahir (2014) mendefinisikan agency cost adalah biaya yang dikeluarkan guna memastikan manajer untuk bertindak sesuai kepentingan pemegang saham. Adanya agency cost ini disebabkan oleh pengaruh konflik antara manajer dan pemegang saham. Konflik kepentingan yang terjadi antara manajer dan pemegang saham akan menimbulkan biaya yang berlebih yaitu free cash flow. Manajer biasanya lebih senang untuk menginvestasikan lagi dana dari free cash flow pada proyek-proyek yang dapat menghasilkan keuntungan, karena hal ini dapat meningkatkan insentif yang diterimanya. Di sisi lain, pemegang saham berharap dari sisa dana tersebut dapat dibagikan sehingga akan meningkatkan kemakmuran dan kesejahteraan pemegang saham.

\section{Transparansi Informasi}

Partha \& Noviari (2016) menjelaskan transparansi informasi diartikan sebagai ketersediaan informasi tentang perusahaan bagi pengguna publik serta menjadi tata kelola perusahaan yang efektif untuk mengurangi konflik kepentingan antara pemegang saham dan manajer. Theresia \& Nuritomo (2016) menjelaskan bahwa konflik keagenan ini muncul karena adanya masalah keagenan. Dalam menghadapi masalah keagenan, transparansi informasi dapat mengurangi konflik keagenan antara pemegang saham dan manajer, agar nilai pasar yang menggeser arus kas dapat disesuaikan melalui pengambilan keputusan manajemen.

Salah satu konsep untuk melihat transparansi informasi pada perusahaan dapat dilihat dengan pelaporan informasi CSR di Indonesia, dengan pelaporan berdasarkan G4 Global Reporting Initiative (GRI-G4) Pradipta (2015). Pelaporan CSR berdasarkan GRI-G4 terdiri dari tiga kategori yaitu ekonomi, lingkungan, dan sosial. GRI-G4 memiiki 91 indikator pengungkapan CSR.

\section{Pengembangan Hipotesis}

\section{Pengaruh Agency Cost Terhadap Nilai Perusahaan}

Agency cost merupakan biaya yang muncul ketika terjadi konflik kepentingan antara manajer dan pemegang saham. Konflik kepentingan antara manajer dan pemegang saham akan menimbulkan biaya yang berlebih yaitu free cash flow. Manajer biasanya lebih suka untuk menginvestasikan lagi dana dari free cash flow pada proyek-proyek yang dapat menghasilkan keuntungan, karena hal ini dapat meningkatkan insentif yang diterimanya. Di sisi lain, pemegang saham berharap dari sisa dana tersebut dapat dibagikan sehingga akan meningkatkan kemakmuran pemegang saham.

Apabila agency cost pada suatu perusahaan tinggi, maka nilai perusahaan 
akan semakin menurun. Ketika manajer berusaha untuk melindungi dirinya sendiri dengan tata kelola internal dan eksternal, maka manajer memiliki kesempatan untuk mendapatkan insentif guna kepentingan pribadi manajer dengan mengorbankan pemegang saham, karena manajer cenderung menilai dari investasi yang dilakukan oleh pemegang saham. Semakin tinggi biaya agensi, maka semakin rendah nilai perusahaan. Hasil penelitian tersebut diperkuat dengan adanya penelitian yang dilakukan oleh Mustapha (2011), Wellalage \& Locke (2013) serta Chung \& et al (2005) menemukan bahwa agency cost berpengaruh negatif terhadap nilai perusahaan.

$\mathrm{H}_{1}$ : agency cost berpengaruh negatif terhadap nilai perusahaan

\section{Transparansi Informasi Dapat Memperlemah Pengaruh Negatif Agency Cost terhadap Nilai Perusahaan}

Chen (2014) mengemukakan bahwa agency cost berperan sebagai variabel yang dapat mengendalikan atau mengurangi terjadinya konflik kepentingan antara manajemen dan pemegang saham. Agency cost merupakan biaya yang diberikan oleh pemegang saham untuk manajer agar dapat menjalankan perusahaan sesuai dengan keinginan prinsipal. Dengan adanya transparansi informasi yang kuat, kemampuan untuk terjadinya konflik kepentingan akan rendah.

Perusahaan yang memiliki transparansi informasi yang tinggi menunjukkan perusahaan harus memberikan informasi yang tepat dan akurat untuk pihak yang berkepentingan. Informasi yang tepat dan akurat ini adalah informasi yang dapat mempengaruhi naik turunnya harga saham perusahaan serta dapat mempengaruhi secara signifikan risiko dan prospek usaha perusahaan yang bersangkutan.

Ketika agency cost pada suatu perusahaan tinggi, maka nilai perusahaan akan turun. Ketika manajer berusaha melindungi dirinya sendiri dengan tata kelola internal dan eksternal, maka manajer memiliki kesempatan untuk mendapatkan insentif guna kepentingan pribadi manajer dengan cara mengorbankan kepentingan pemegang saham. Hal ini terjadi karena manajer cenderung menilai dari investasi yang dilakukan oleh pemegang saham.

$\mathrm{H}_{2}$ : transparansi informasi dapat memperlemah pengaruh negatif agency cost terhadap nilai perusahaan

Model kerangka konseptual dapat dilihat pada gambar berikut:

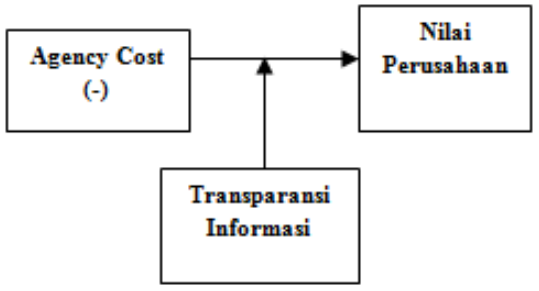

Gambar 1

Kerangka Konseptual

\section{Metode Penelitian}

\section{Jenis Penelitian yang digunakan}

Penelitian ini mengggunakan data sekunder. Data penelitian diperoleh dengan mengunduh pada website Bursa Efek Indonesia. Populasi yang digunakan dalam penelitian ini adalah perusahaan manufaktur yang terdaftar di Bursa Efek Indonesia tahun 2013-2017.

\section{Populasi dan Sampel}

Populasi dari penelitian ini adalah perusahaan manufaktur yang terdaftar di Bursa Efek Indonesia periode 2013-2017. Jumlah perusahaan yang digunakan pada periode tersebut sebanyak 262 perusahaan. Sampel yang digunakan menggunakan teknik purposive sampling dengan kriteria yang dibutuhkan dari perusahaan antara lain (1) Perusahaan merupakan kelompok perusahaan manufaktur go public dan tidak pernah delisting di BEI selama tahun pengamatan yaitu tahun 2013-2017, (2) Mempublikasikan laporan tahunan dan laporan keuangan tahunan pada tahun 2013- 
2017 yang dapat diakses melalui situs BEI, (3) Mempunyai laporan keuangan lengkap yang berakhir 31 Desember dari tahun 2013-2017, (4) Laporan keuangan yang penyajiannya dengan menggunakan mata uang rupiah, (5) Tidak sedang mengalami kerugian pada periode tahun 2013-2017, (6) data yang disajikan lengkap dan memenuhi semua variabel yang digunakan dalam penelitian.

\section{Definisi dan Pengukuran Variabel Nilai Perusahaan}

Nilai perusahaan adalah persepsi investor terhadap tingkat keberhasilan perusahaan yang sering dikaitkan dengan harga saham. Nilai perusahaan diproksikan dengan PBV (Price to Book Value). Pengukuran ini dapat dirumuskan sebagai berikut:

\section{PBV = Harga per lembar saham Nilai buku per lembar saham}

\section{Agency Coct}

Agency cost adalah biaya yang diberikan oleh pemegang saham untuk manajemen agar dapat menjalankan perusahaan sesuai dengan keinginan prinsipal (Adityamurti \& Ghozali, 2017). Agency cost dalam penelitian ini diukur dengan pendekatan free cash flow. Dalam penelitian ini free cash flow diperoleh dari selisih arus kas aktivitas operasi dan arus kas investasi (Yogi \& Damayanthi, 2016). Selanjutnya free cash flow dibagi dengan total aset pada periode yang sama. FCF dapat dihitung menggunakan rumus berikut:

\section{FCF = CFO - CFI X 100\% \\ Total Aset}

Keterangan:

FCF : Free Cash Flow (Arus Kas

Bebas)
CFO : Arus Kas Operasi
CFI : Arus Kas Investasi

\section{Transparansi Informasi}

Partha \& Noviari (2016) menjelaskan transparansi informasi merupakan ketersediaan informasi tentang perusahaan untuk investor atau masyarakat yang berfungsi sebagai tata kelola perusahaan guna mengurangi konflik kepentingan antara manajemen dengan pemegang saham. Pengukuran transparansi informasi menggunakan di proksikan pada voluntary disclosure (pengungkapan sukarela) dimana pengungkapan tersebut adalah pengungkapan yang dilakukan secara sukarela oleh perusahaan tanpa di haruskan oleh peraturan yang berlaku.

$$
\text { Pengukuran pengungkapan }
$$
sukarela pada penelitian ini mengacu pada pengungkapan Corporate Social Responsibility yang menggunakan standar yang diterapkan oleh Global Reporting Invitative (GRI-G4) mengikuti penelitian yang dilakukanoleh (Pradipta, 2015). Rumus perhitungannya sebagai berikut:

\section{CSRIj $\quad=\frac{\mathbf{n}}{\mathbf{k}}$}

Keterangan:

$$
\begin{array}{ll}
\text { CSRIj } & : \text { Indeks luas pengungkapan pada } \\
& \text { perusahaan } \mathrm{j} \\
\mathrm{n} & : \begin{array}{l}
\text { Jumlah butir pengungkapan } \\
\text { yang dipenuhi }
\end{array} \\
\mathrm{k} \quad: \begin{array}{l}
\text { Jumlah semua butir yang } \\
\text { mungkin dipenuhi }
\end{array}
\end{array}
$$

CSRIj dilakukan menggunakan:

$$
\begin{array}{llr}
\text { score } 0: \begin{array}{l}
\text { jika perusahaan tidak } \\
\text { mengungkapkan } \\
\text { checklist }
\end{array} & \begin{array}{r}
\text { item } \\
\text { chem }
\end{array}
\end{array}
$$

score 1 : Jika perusahaan mengungkapkan item check list

\section{Sumber Data dan Teknik Pengolahan Data}

Metode analisis data menggunakan statistik deskriptif, uji asumsi klasik yang terdiri dari uji normalitas, uji multikolinearitas, uji autokorelasi, uji heteroskedastisitas, untuk uji hipotesis menggunakan analisis regresi berganda dan uji nilai selisih mutlak, uji model, uji koefisien determinasi, dan uji t.

Pengujian hipotesis penelitian ini menggunakan analisis regresi sederhana 
dan uji nilai selisih mutlak Analisis regresi sederhana terdukung apabila nilai sig < 0,05. Adapun persamaan regresi sederhana untuk pengujian hipotesis adalah sebagai berikut:

$\mathrm{Y}=\alpha_{0}+\beta_{1} \mathrm{X}_{1}+\varepsilon$

Dengan keterangan:

Y : Nilai perusahaan

A : Konstanta

$\beta_{1} \quad$ : Koefisien regresi linier $\mathrm{X}$

$\mathrm{X}_{1} \quad$ : Agency cost

$\mathrm{E} \quad$ : Eror

Berikut persamaan regresi untuk variabel moderasi yaitu dengan uji nilai selisih mutlak yaitu dengan persamaan berikut:

$\mathrm{Y}=\alpha_{0}+\beta_{1} \mathrm{X}_{1}+\beta_{2} \mathrm{X}_{2}+\beta_{3}\left(\mathrm{X}_{1} \mathrm{X}_{2}\right)+\varepsilon$

Dengan Keterangan:

Y : Nilai perusahaan

$\alpha \quad$ : Konstanta

$\beta 1 \beta 2 \beta 3 \quad$ : Koefisien regresi linier $X$

$\mathrm{X}_{1} \quad$ : Agency cost

$\mathrm{X}_{2} \quad$ : Transparansi informasi

$\varepsilon \quad:$ Eror

\section{Hasil Penelitian dan Pembahasan}

\section{Uji Asumsi Klasik}

Dari uji hasil asumsi klasik yang terdiri dari uji normalitas, uji multikolinearitas, uji autokorelasi, dan uji heteroskedastisitas yang telah dilakukan dapat disimpulkan bahwa variabel yang digunakan dalam penelitian ini seperti agency cost, transparansi informasi, nilai perusahaan terbebas dari uji asumsi klasik.

\section{Uji Hipotesis}

\section{Uji Regresi Berganda} Hasil Uji Simultan ( Uji F)

\section{Tabel 1}

\section{Uji F}

\begin{tabular}{|c|c|c|c|c|c|}
\hline & Sum of & & Mean & & \\
\hline Model & Squares & df & Square & $F$ & Sig. \\
\hline I Regression & 171,559 & 2 & 85,779 & 23,701 & $.000^{3}$ \\
\hline Residual & 865,008 & 239 & 3,619 & & \\
\hline Total & 1036,567 & 241 & & & \\
\hline
\end{tabular}

Berdasarkan hasil uji kecocokan model dapat diketahui $\mathrm{F}$ hitung 23,701 dan nilai $\mathrm{p}$ sebesar 0,000. Dapat disimpulkan bahwa $\mathrm{p}<0,05$, maka hipotesis diterima. Artinya, variabel independen (agency cost) berpengaruh terhadap nilai perusahaan. Dengan kata lain model dalam penelitian ini sudah fit.

\section{Hasil Uji Parsial (Uji t)}

Tabel 2

\section{Hasil Uji T}

\begin{tabular}{ccccc}
\hline \multicolumn{5}{c}{ Unstandardized } \\
Model & B & Std. Error & $T$ & Sig. \\
\hline C & 4.363 & .301 & 14.511 & .000 \\
LN_X1 & .859 & .137 & 6.282 & .000 \\
\hline a. Devendent Variable:LN Y & & &
\end{tabular}

Pengujian hipotesis ini dilakukan untuk membuktikan pengaruh agency cost terhadap nilai perusahaan yang dilakukan dengan pengujian statistik. Dari hasil regresi menunjukkan bahwa agency cost berpengaruh positif terhadap nilai perusahaan. Hal ini terlihat pada tabel 2 yang menunjukkan nilai signifikansi 0,000 dan nilai $t$ hitung sebesar 6,282. Berdasarkan hasil penelitian tersebut maka hipotesis kedua menyatakan bahwa agency cost berpengaruh negatif terhadap nilai perusahaan tidak dapat diterima. Hasil penelitian ini sejalan dengan penelitian yang dilakukan oleh Adityamurti \& Ghozali (2017), Chen et al (2016), dan Andini \& Wirawati (2014) yang menyatakan bahwa agency cost berpengaruh positif terhadap nilai perusahaan. 


\section{Uji Nilai Selisih Mutlak}

\section{Hasil Uji Simultan ( Uji F)}

Tabel 3

Uji F

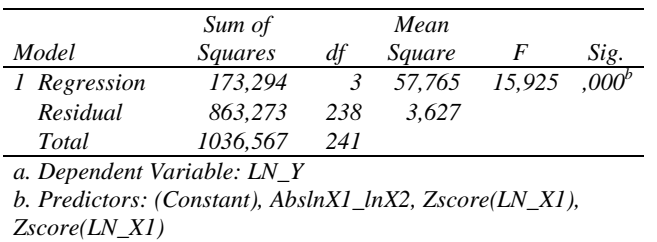

Tabel 3 menunjukkan bahwa hasil anova atau $\mathrm{F}$ test menunjukkan bahwa nilai $\mathrm{F}$ hitung sebesar 715,925 dengan tingkat signifikansi 0,000 jauh dibawah 0,05 . Hal ini menunjukkan bahwa variabel independen ZLn_agency cost ZLn_transparansi informasi dan AbsLnX1_X2 secara bersama-sama atau simultan mempengaruhi nilai perusahaan.

\section{Hasil Uji Parsial (Uji t)}

Tabel 4

Hasil Uji T

\begin{tabular}{lcccc}
\hline \multicolumn{5}{c}{ Unstandardized } \\
Model & B & Std. Error & $T$ & Sig. \\
\hline C & 2.745 & .212 & 12.955 & .000 \\
Zscore(LN_X1) & .696 & .136 & 5,131 & .000 \\
Zscore(LN_X2 $_{\text {s }}$ & .314 & .130 & 2.422 & .016 \\
AbsLnX1_LnX2 & -.118 & .170 & -.692 & .490 \\
\hline a. Dependent Variable: LN_Y & & &
\end{tabular}

Pengujian hipotesis ini dilakukan untuk membuktikan dengan adanya transparansi informasi dapat memperlemah pengaruh negatif agency cost terhadap nilai perusahaan. Hal ini terlihat pada tabel 4 yang menunjukkan variabel moderasi AbsLnx1_Lnx2 memiliki nilai 0,490 lebih dari dari 0,05 , sehingga tidak signifikan.
Berdasarkan hasil penelitian tersebut menunjukkan bahwa hipotesis keempat yang menyatakan bahwa transparansi informasi dapat memperlemah pengaruh negatif agency cost terhadap nilai perusahaan tidak dapat diterima.

Pengaruh Agency Cost Terhadap Nilai Perusahaan

Hasil uji regresi pengaruh agency cost terhadap nilai perusahaan menunjukkan bahwa variabel agency cost positif signifikan pada variabel nilai perusahaan. Penelitian ini didukung oleh penelitian yang dilakukan oleh (Adityamurti \& Ghozali, 2017) yang membuktikan bahwa agency cost berpengaruh positif terhadap nilai perusahaan. Dengan demikian dapat memberi bukti bahwa semakin tinggi agency cost yang pemegang saham berikan terhadap manajer, maka hal tersebut dapat meningkatkan nilai perusahaan pula. Hasil penelitian ini sesuai dengan teori kesempatan investasi yang menyatakan bahwa investor atau pemegang saham makan mendukung perusahaan yang memiliki substansial free cah flow dan kesempatan investasi yang menguntungkan di dalam valuasi saham.

Ketika free cash flow pada suatu perusahaan tinggi, maka nilai perusahaan juga akan semakin tinggi. Perusahaan yangh memiliki free cash flow yang tinggi dapat menghasilkan return yang lebih baik daripada perusahaan dengan free cash flow yang rendah. Hal tersebut akan membuat manajer menggunakan free cash flow baik untuk kepentingan perusahaan maupun kepentingan pemegang saham.

\section{Transparansi Informasi Dapat Memperlemah Pengaruh Negatif Agency Cost terhadap Nilai Perusahaan}

Hasil uji nilai selisih mutlak transparansi informasi dapat memperlemah pengaruh negatif agency cost terhadap nilai perusahaan tidak signifikan. Berdasarkan hasil penelitian tersebut menunjukkan bahwa hipotesis yang menyatakan transparansi informasi dapat memperlemah 
pengaruh negatif agency cost terhadap nilai perusahaan tidak dapat diterima. Hal ini disebabkan karena adanya transparansi informasi yang perusahaan berikan terhadap publik tidak akan mempengaruhi dalam pengambilan keputusan pemegang saham dalam melakukan investasi modalnya terhadap suatu perusahaan, dengan alasan pemegang saham biasanya lebih melihat keuntungan atau profit yang perusahaan dapatkan daripada melihat transparansi informasi atau CSR yang perusahaan berikan terhadap publik.

Kurangnya transparansi informasi yang diberikan oleh manajer/ perusahaan dalam pengungkapan sukarela (CSR) terhadap investor dapat membuat manajer melakukan agency cost dengan memanfaatkan free cash flow untuk keputusan investasi agar dapat meningkatkan nilai perusahaan. Hal ini harus menjadi perhatian bagi pemegang saham untuk melakukan pengawasan serta pengendalian internal yang optimal agar manajemen tidak memanfaatkan agency cost agar ma.najer tidak memiliki niatan untuk memanfaatkan agency cost untuk kepentingan pribadinya serta untuk memaksimumkan nilai perusahaan. Di samping itu, dapat mendorong manajer untuk mengoptimalkan kegiatan operasinya dengan cara memiliki produk, jasa, serta mempertahankan reputasi yang baik di mata konsumen, dan pemangku kepentingan lainnya sehingga laba yang dihasilkan terus meningkat dan berdampak pada peningkatan nilai perusahaan.

\section{Simpulan dan Saran}

\section{Simpulan}

Penelitian ini bertujuan untuk mengetahui pengaruh agency cost terhadap nilai perusahaan dengan transparansi informasi sebagai variabel moderasi. Berdasarkan analisis data dan pembahasan yang telah dilakukan, maka dapat disimpulkan bahwa agency cost berpengaruh positif terhadap nilai perusahaan. Transparansi informasi tidak dapat memperlemah pengaruh negatif agency cost terhadap nilai perusahaan.

Keterbatasan pada penelitian ini adalah penelitian masih terdapat penilaian yang subjektivitas dalam menentukan pengungkapan sukarela (CSR) yang perusahaan lakukan dalam hal penilaian pada indikator yang ada pada pengungkapan sukarela (CSR). Hal tersebut dengan alasan tidak ada standar khusus yang dapat dijadikan sebagai patokan untuk penilaian pengungkapan sukarela (CSR) sehingga hal tersebut dapat menyebabkan timbulnya banyak asumsi yang berbeda. Pada penelitian ini terbatas untuk hanya meneliti perusahaan manufaktur, sehingga hasil yang diperoleh dalam penelitian tidak bisa digeneralisasikan pada bentuk perusaahaan pada bidang yang lain yang ada di Indonesia. Terkait dengan adanya unsur subjektivitas telah diungkapkan di atas, sebelum melakukan penelitian sebaiknya dapat dilakukan penilaian dengan berapa peneliti dilakukannya penilaian (scoring) pada item-item pengungkapan sukarela CSR) yang perusahaan ungkapkan serta dalam memilih variabel yang lain untuk pengujian variabel independen nilai perusahaan dengan tahun yang berbeda atau menambah tahun pengamatan. Pengambilan jenis industri lainnya juga bisa dilakukan untuk memperoleh perbandingan antara jenis industri yang berbeda.

Berdasarkan hasil penelitian yang dilakukan maka dapat kita ketahui bahwa agency cost berpengaruh positif terhadap nilai perusahaan sedangkan transparansi informasi tidak dapat memoderasi pengaruh agency cost terhadap nilai perusahaan. Maka implikasi dari penelitian ini adalah perusahaan yang mempunyai agency cost yang tinggi maka akan memiliki nilai perusahaan yang tinggi, karena hal tersebut dapat dijadikan pemegang saham untuk mengawasi tindakan manajer guna menunjang nilai 
perusahaan agar semakin lebik baik lagi. Adanya transparansi informasi yang diberikan perusahaan kepada investor atau pemegang saham tidak dapat berpengaruh terhadap minat mereka untuk berinvestasi, karena investor dan pemegang saham biasanya lebih cenderung melihat laba atau profit yang akan mereka dapatkan dengan melihat laporan laba rugi perusahaan daripada melihat transparansi informasi yang perusahaan berikan melalui tanggung jawab sosial (CSR), sehingga transparansi informasi yang perusahaan berikan tidak memberikan efek yang menguatkan investor atau pemegang saham dalam memutuskan untuk menginvestasikan modalnya atau tidak pada perusahaan.

\section{Saran}

Berdasarkan hasil penelitian dan pembahasan sebelumnya, maka dapat ditarik beberapa saran sebagai berikut:

1. Untuk penelitian selanjutnya bisa meneliti dengan menggunakan periode penelitian yang berbeda dan dengan objek penelitian yang berbeda misalnya di sektor perbankan, infrastruktur, property dan real estate.

2. Penelitian selanjutnya dapat menambah jangka waktu lima tahun sehingga data lebih memperlihatkan kondisi perusahaan yang sebenarnya.

3. Penelitian mengenai agency cost merupakan penelitian yang masih baru di Indonesia sehingga peneliti selanjutnya dapat melanjutkan studi literatur tentang agency cost berpengaruh terhadap variabel lain misalnya cash holding, capital investment, dan transfer pricing.

\section{Daftar Pustaka}

Adityamurti, E., \& Ghozali, I. (2017). Pengaruh Penghindaran Pajak dan Biaya Agensi Terhadap Nilai Perusahaan. Jurnal of Accounting, 6(03), 1-12.
Andini, N. W. L., \& Wirawati, N. G. P. (2014). Pengaruh Cash Flow Pada Kinerja Keuagan Dan Implikasinya Pada Nilai Perusahaan Manufaktur. E-Jurnal Akuntansi Udayana 7.1, 1, 107-121.

Chen. (2014). No Title.

Chen, Z., \& et al. (2016). Corporate Tax Avoidance and Performance: Evidence from China' $\mathrm{s}$ Listed Companies. ZhaInstitutions and Economies, 8(3), 61-83.

Chung, R., \& et al. (2005). FCF Agency Cost, Earnings Management, and Investor Monitoring, 2(4), 51-61.

Djumahir. (2014). Pengaruh Biaya Agensi, Tahap Daur Hidup Perusahaan , dan Regulasi terhadap Kebijakan Dividen pada Perusahaan Manufaktur di Bursa Efek Indonesia. Jurnal Manajemen Dan Kewirausahaan, 11, 144-153.

Erawati, T., \& Latifah, A. I. (2018). Pengaruh Perencanaan Pajak (Tax Planning) terhadap Nilai Perusahaan dengan Corporate Social Responsibility (CSR) sebagai Variabel Moderating. Jurnal Akuntansi, 1-13.

Ferreira, M. A., \& Vilela, A. S. (2004). Why Do Firms Hold Cash? Evidence from EMU Countries, 10(2), 295319.

Harventy, G. (2016). Pengaruh Tax Avoidance Terhadap Nilai Perusahaan, 6(2), 895-906.

Khan, A., \& et al. (2012). Impact of Financial Leverage on Agency cost of Free Cash Flow: Evidence from the Manufacturing sector of Pakistan, 2(7), 6694-6700.

Mustapha, M. (2011). Agency theory and managerial ownership : evidence from Malaysia,

(May) https://doi.org/10.1108/02686901111 129571

Partha, I. G. A., \& Noviari, N. (2016). Pengaruh Penghindaran Pajak Jangka Panjang Pada Niai Perusahaan Dengan Transparansi Informasi 
Sebagai Variabel Pemoderasi, 3, 2336-2362.

Pradipta, R. H. (2015). Pengaruh Corporate Social Responsibility dalam Perspektif Lingkungan terhadap Manajemen Laba.

Sugiyanto. (2016). Pengaruh Tax Avoidance Terhadap Nilai Perusahaan dengan Pemoderasi Kepemilikan Institusional.

Theresia, O., \& Nuritomo. (2016). Pengaruh Penghindaran Pajak Terhadap Nilai Perusahaan Dengan Transparansi Informasi Sebagai Variabel Pemoderasi Pada Perusahaan Manufaktur Yang Terdaftar di Bursa Efek Indonesia Tahun 2013-2015, 1-18.

Wardani, D. K., \& Juliani. (2018). Pengaruh Tax Avoidance terhadap Nilai Perusahaan dengan Corporate Governance sebagai Variabel Pemoderadi, VII.

Wellalage, N. H., \& Locke, S. (2013). Women on board, Firm Financial Performance and Agency Costs, 2, 113-127.

https://doi.org/10.1007/s13520-0120020-x

www.britama.com. (2016). Kinerja 2016: Bata Catat Penurunan Laba Bersih Menjadi Rp42,23 Milyar. Retrieved from https://britama.com/index.php/2017

Yogi, L. M. D. P., \& Damayanthi, I. G. A. E. (2016). Pengaruh Arus Kas Bebas, Capital Adequacy Ratio dan Good Corporate Governance pada Manajemen Laba, 15, 2302-8556. 